\title{
Physico-Chemical Characteristics of Potable Water in Chitrakoot Region District
}

\author{
Arvind Prasad Dwived \\ Lecturer, Department of chemistry, Govt. Sanjya Gandhi Smrati Auto P.G.College Sidhi M.P.,India
}

*Corresponding Author: Arvind Prasad Dwived, Lecturer, Department of chemistry, Govt. Sanjya Gandhi Smrati Auto P.G. College Sidhi M.P., India

\begin{abstract}
The chitrakoot is geographically located at coordinated $25.00^{\circ} \mathrm{N}$ latitude \& $80.83^{\circ} \mathrm{E}$ longitude. The present study is focused on water quality assessment for month of April 2013.The water quality for direct human consumption should be i.e. it should be pure i.e. without impurities. It need not be chemically pure, infect the portable water should essentially have some mineral in order to give it some taste. The Procedures followed to analyze the physico-chemical parameters were from Standard Methods Most of stations were found higher values of hardness. Due to higher hardness values import economic pressure on consumer. Values of total dissolved solid were higher at some stations and other stations samples are under limit. DO and BOD of common studied potable water is also under limit as per prescribed WHO guidelines.
\end{abstract}

Keywords: Physico-chemical parameters, Potable water, Chitrakoot Region

\section{INTRODUCTION}

Chitrakoot is atown and a nagar panchayat in satna District in the state madhya pradesh, India. It is a town of religious, cultural, historical and archaeological importance, situated in the Bundelkhand region. The chitrakoot is geographically located at coordinated $25.00^{\circ} \mathrm{N}$ latitude $\& 80.83^{\circ} \mathrm{E}$ longitude. It borders the chitrakoot district in Utter Pradesh, whose headquarters chitrakoot Dham (karwi) is located nearby ${ }^{1 .}$

Water is one of the basic materials, which is of prime importance for the preservation of life on the surface of the earth. For the resistance of all living being (humans, animals or plants) water we cannot survive almost all-human activities-domestic, agricultural and industrial demand use of water. Although water is nature's most wonderful compound but only less than 15 of the world is water resources are available for ready use. Hence, It is urgently required to use the available water most carefully ${ }^{2}$ The identification of water quality depends on the intended use of the water which may be consumptive (human consumption) and no consumptive (industries, agriculture, irrigation account for more than $2 / 3^{\text {rd }}$ of the total human use), power generation, recreation etc.), depending upon the purpose uses of water. Certain quality criteria are established and based on these criteria; quality standards are specified by health and other regulating agencies to ensure that the water quality in a resource is suitable for the purposed use. Different type of water use requires different levels of water purity. Drinking water requires the highest standards of purity where as water of relatively lower quality is acceptable for other purposes like agriculture, industries, fisheries, wild life, livestock, recreation, hydro electric power, waste disposal etc.

The water quality for direct human consumption should be i.e. it should be pure i.e. without impurities. It need not be chemically pure, infect the portable water should essentially have some mineral in order to give it some taste. Portable water should conform the water quality standard set for human consumption that are. It should te tasteless and odorless. It should be clear i.e. free of suspended solid and turbidity. It should be free of pathogenic organism. The dissolved inorganic solids should be in moderate quantities.Potable water should be moderately soft (50-100ppm), even slight hardness of 100-150 ppm is substances that may have serious long- term effects. It should be non corrosive to pipe and should not cause any incrustations in the pipes. The $\mathrm{pH}$ value should be preferable between $1 \& 8.5$. It should be aesthetically pleasant i.e. fresh and cool. It should not stain clothes. $^{3}$ 
In India, most of the population is dependent on surface water (damp water) as the only source of drinking water supply. The groundwater is believed to be comparatively much clean and free from pollution than surface water. But prolonged discharge of industrial effluents, domestic sewage and solid waste dump causes the groundwater to become polluted and created health problems ${ }^{4}$.

The haphazard urbanization coupled with poor disposal practices unhygienic sanitation emphasized further cross section of the local community about observed anomalies further cross section of the local community about observed anomalies in ground water, it was decided to take up a detailed qualitative inter predation of ground water in identified areas of chitrakoot, objective of the parent study are: To identified the potable water quality of study area. To learn various types of instrument related to potable water quality analysis. To find out the current Development in the field of potable water Quality and its impact. To know the experimental method at the area monitoring and analysis technique. ${ }^{5}$

\section{MATERIALS AND METHODS}

\subsection{Sample Collection}

The samplings were chosen at different site of the study area. The present study is focused on water quality assessment for month of April 2013. For testing the water samples were collected in different sterile plastic bottles were tightly capped and were immediately transported to the laboratory to avoid any unpredictable changes in the Physico-chemical characteristics.

Samples are taken at regular intervals and it is essential that the collected sample be truly representative of the product of final water. Sample should be collected in clean, dry and Stoppard bottle. The bottle is rinsed thoroughly before collection of sample. Stopper the bottle after collection of the sample. The samples are to be preserved in refrigerators in the analysis is subjected to a delay of more than 24 hover, to avoid any biological activity within the sample. Attach a tag on the sample bottle or other container indicating, date time name of the sample and testes to be carried out. The samples were refrigerated at $4^{0} \mathrm{C}$ in the laboratory. The Procedures followed to analyze the physicochemical parameters were from Standard Methods (APHA 1984). ${ }^{5}$

Table1. List of Sampling Stations

\begin{tabular}{|c|c|c|c|c|}
\hline S.No. & Sampling Station with code & Water Source & Depth in fit & Description of sampling location \\
\hline 1 & Govt. School Rajola $\mathrm{R}_{1}$ & Hand Pump & 80 & Village Rajola Chitrakoot \\
\hline 2 & Hanuman JiMandir $\quad \mathrm{R}_{2}$ & Hand Pump & 70 & $\begin{array}{l}\text { Raja Rajiv Mahal Rajola } \\
\text { Chitrakoot }\end{array}$ \\
\hline 3 & University Campus $\quad \mathrm{R}_{3}$ & Tubal & 130 & MGCGV Chitrakoot \\
\hline 4 & Sphtik Sila Mod & Hand Pump & 70 & Sphetik Silas Mod \\
\hline 5 & Police Mace & Hand Pump & 70 & Police Mace Chitrakoot \\
\hline 6 & DRI Campus & Tubal & 140 & DRI Campus Chitrakoot \\
\hline 7 & Dubay House & Hand Pump & 80 & Adarsh Nagar Chitrakoot \\
\hline 8 & PHE office & Tubal & 180 & $\begin{array}{l}\text { PHE Office Arogya Dham } \\
\text { Chitrakoot }\end{array}$ \\
\hline 9 & Satna Bus Stand & Hand Pump & 70 & Satna Bus Stand Chitrakoot \\
\hline 10 & Janki Kund Hospital $\mathrm{R}_{10}$ & Tubal & 160 & $\begin{array}{l}\text { Janki Kund Eye Hospital } \\
\text { Chitrakoot Siya Ram Kuti } \\
\text { ram Ghat Chitrakoot }\end{array}$ \\
\hline 11 & Siya Ram Kuti & Hand Pump & 70 & $\begin{array}{l}\text { Siya Ram Kuti Ram Ghat } \\
\text { Chitrakoot }\end{array}$ \\
\hline 12 & Samaj Bodi Party Office $R_{12}$ & Hand Pump & 80 & $\begin{array}{l}\text { Bi Pass Road Ram Ghat } \\
\text { Chitrakoot }\end{array}$ \\
\hline 13 & $\begin{array}{l}\text { Duatiya Mukhar Bindu Kamda } \\
\text { Nath } R_{13}\end{array}$ & Hand Pump & 90 & $\begin{array}{l}\text { Duatiya Mukharbind Kamda } \\
\text { Nath Chitrakoot }\end{array}$ \\
\hline 14 & $\begin{array}{l}\text { Nisha Dhar Daram Shala } \\
\text { Kamtan Chitrakoot } \quad \mathrm{R}_{14}\end{array}$ & Tubal & 120 & $\begin{array}{l}\text { Pramukh Mukharbind } \\
\text { Kamda Nath Chitrakoot }\end{array}$ \\
\hline
\end{tabular}

\section{RESULT AND DISCUSSION}

The present dissertation work identifies potable water quality of Chitrakoot. The result pf potable water qualities of chitrakoot are given below. The results of study are given in table-1 and standard are given in table-2. 


\subsection{Temperature}

In the present study of potable water is the lowest temperature of potable water is $24^{\circ} \mathrm{C}$ and highest temperature is $32^{\circ} \mathrm{C}$. All the samples were below the permissible limit prescribed by WHO, 1984.Dwivedi et al.2016, worked the quality assessment of ground water and surface water samples collected from two different zone of central India, Temperature was observed ranged between $10^{\circ} \mathrm{C}$ to $40^{\circ} \mathrm{C}$.

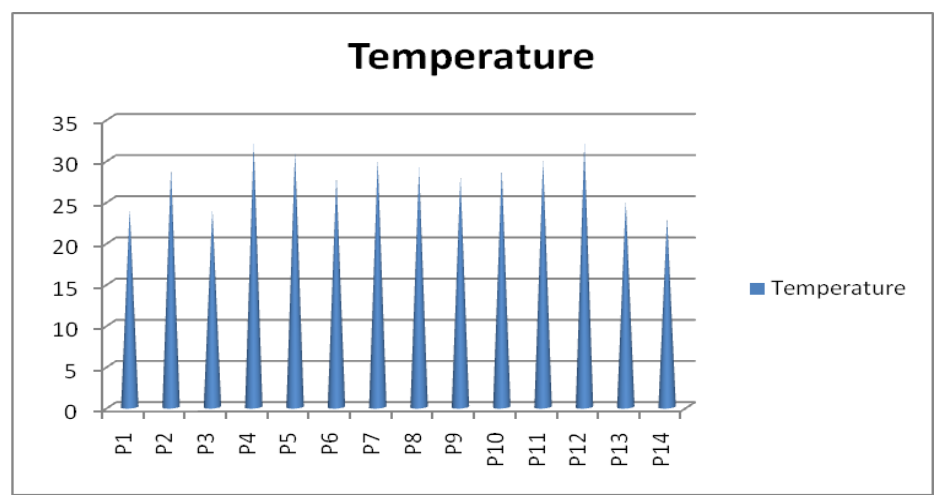

\section{2.pH}

The $\mathrm{pH}$ Values of drinking water samples are between 8.09- 8.99. Low $\mathrm{pH}$ value associated with small amount of mineral acid from chloride source or with organic acid. High $\mathrm{pH}$ value associated with small amount of mineral acid from carbonate source or with inorganic acid. Its highest value found 8.99 and lowest value found 8.09. That is present in between limit of value prescribed by WHO, 1984.Tripathi et al. 2015 studied multivariate analysis of soil and ground water quality in Sidhi District of Vindhya Pradeshand reported the $\mathrm{pH}$ concentrations ranged from 6.20to7.57.

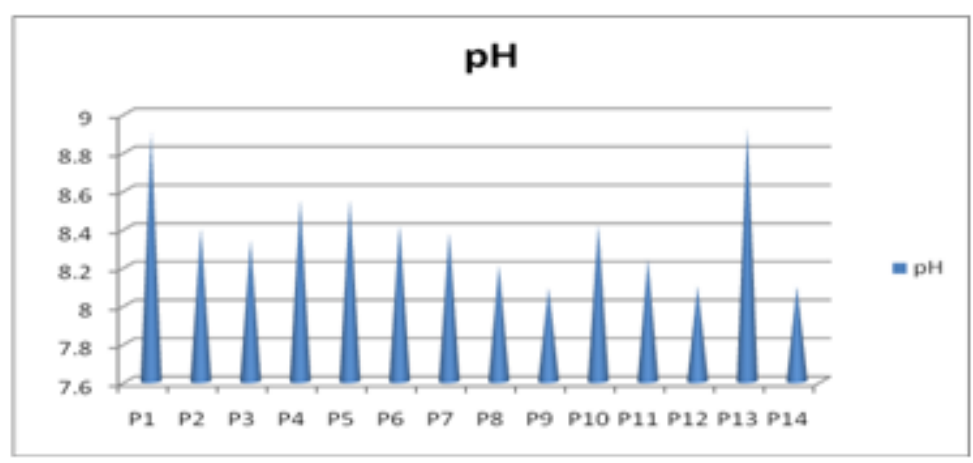

\subsection{Turbidity}

Turbidity of water is also on parameter of potable water quality.In this work thew lowest value 1.29 NTU found and highest value 3.98 NTU. All the samples were below the permissible limit prescribed by WHO, (1984).Dwivedi et al.2015, worked the chemistry of soil and ground water in Panna District of Vindhya Pradesh, turbidity of water was found to be 1.5 to8.0 NTU.

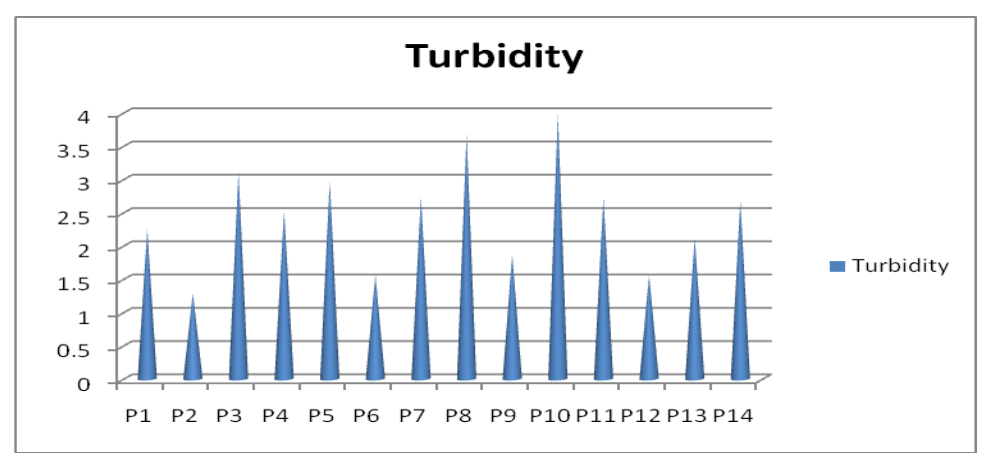

\subsection{Total Dissolve Solid}

The dissolve solid content of a sample of water is important in deciding wither the water suitable for drinking purpose or not .in the present study the value of TDS are $200 \mathrm{mg} / \mathrm{l}$. and the highest value of 
$300 \mathrm{mg} / \mathrm{l}$. Tripathi et al. 2016, studied analysis of Physico-chemical Parameters and correlation coefficient of ground water samples in residential area of east zone of central India, detected the TDS ranged between 245.0 to $534 \mathrm{mg} / \mathrm{l}$.

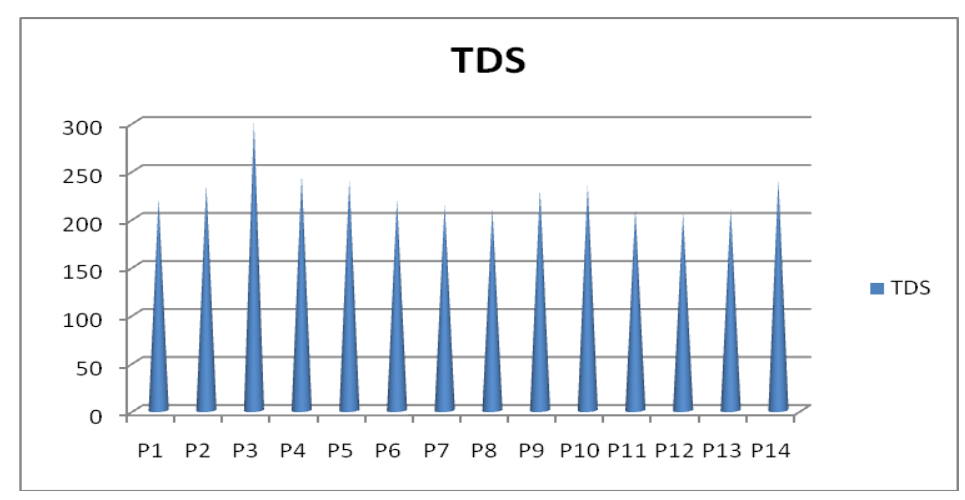

\subsection{Total Hardness}

In present study of TH highest value found $355 \mathrm{mg} / \mathrm{l}$ and lowest value found $249 \mathrm{mg} / \mathrm{l}$. Most of stations were found higher values of hardness. Due to higher hardness values import economic pressure on consumer. Tripathi etal.2015, quality and assessment of ground water in Satna, Madhya Pradesh have reported total hardness to be 320 to $760 \mathrm{mg} / \mathrm{l}$.

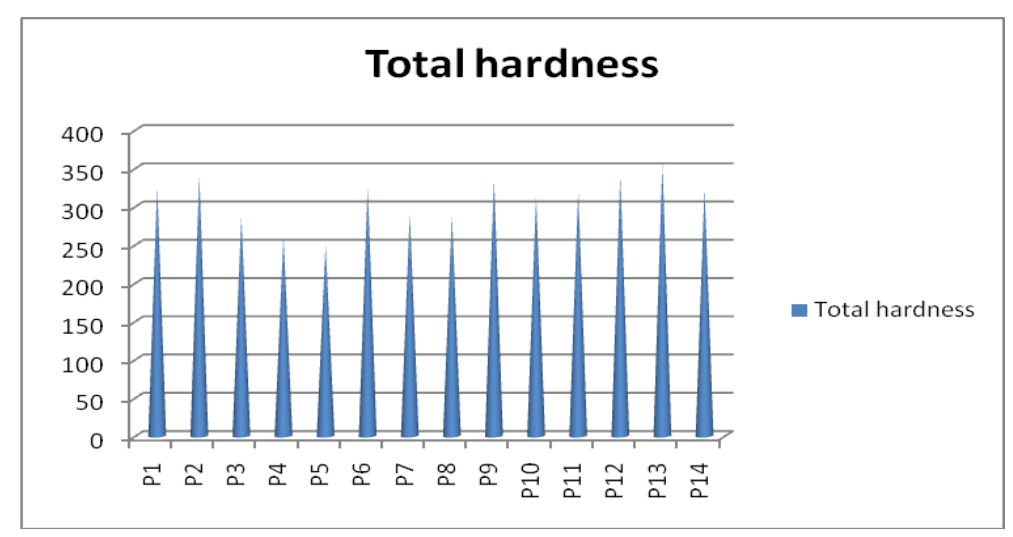

\subsection{Dissolve Oxygen}

The DO value range from $4.93 \mathrm{mg} / \mathrm{l}$ to $7.01 \mathrm{mg} / \mathrm{l}$ the highest $\mathrm{DO}$ was observed of $\mathrm{P}_{10}$ as show in table. Values of DO at P10 exceed limit set by WHO as 4.2- $6.0 \mathrm{mg} / \mathrm{l}$. Dwivedi et al. 2013 carried out assessment of soil and ground water quality in Rewa District of Vindhya Plateau(India) and DO value was observed ranged between 1.0 to $8.7 \mathrm{mg} / \mathrm{l}$.

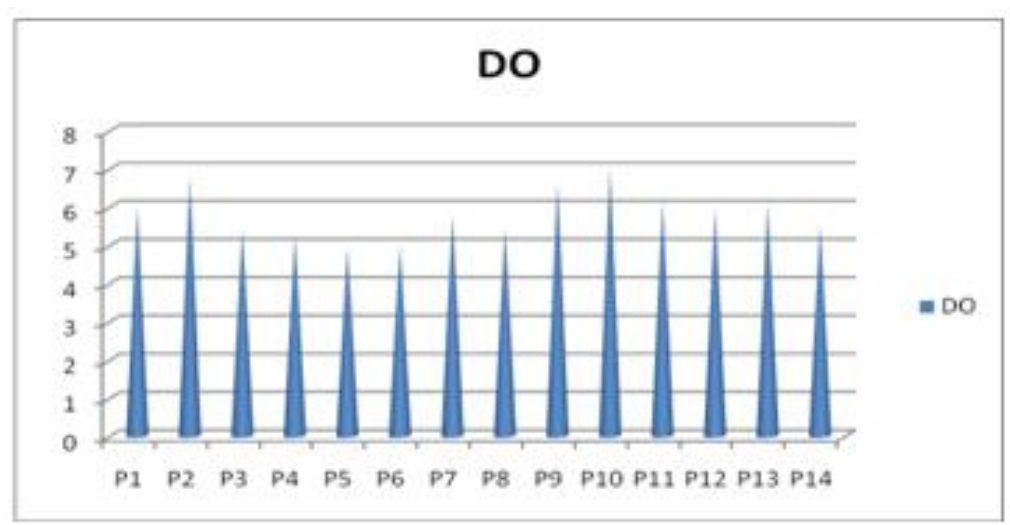

\subsection{Bio-Chemical Demand}

The BOD value range from 4.12 to $7.02 \mathrm{mg} / \mathrm{l}$ the highest $\mathrm{BOD}$ was observed of $\mathrm{P}_{9}$ as show in table. Value of BOD at P9 exceeds limit set by WHO as $6.0 \mathrm{mg} / \mathrm{l}$. Tripathi et al.2013, studied the characterization of Diffuse Chemical pollution in Satna District of Vindhya Region, India, BOD value was found ranged between 1.0 to $7.4 \mathrm{mg} / \mathrm{l}$. 


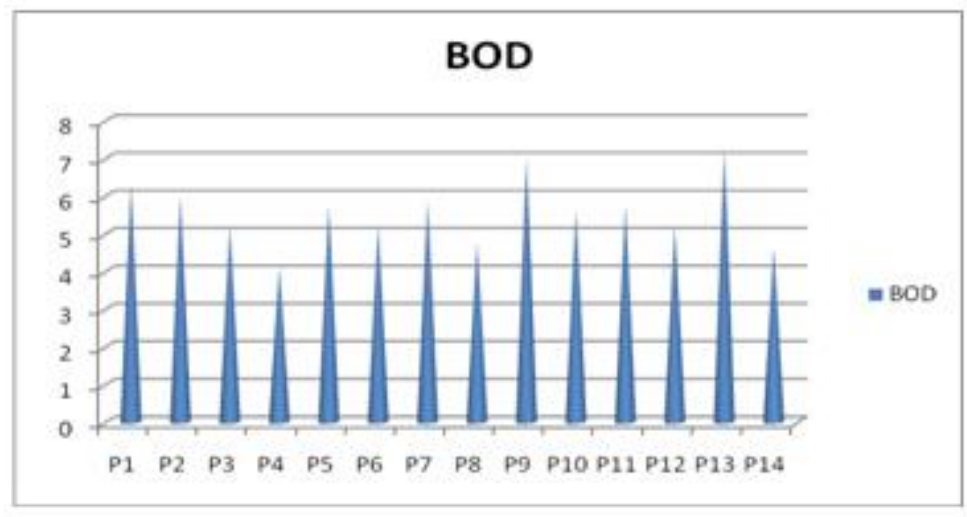

Table1. The Physico-chemical Characteristics of Potable water Different Point of Chitrakoot

\begin{tabular}{|l|l|l|l|l|l|l|l|}
\hline Sampling station & Temperature & pH & TDS & Turbidity & Total Hardness & DO & BOD \\
\hline $\mathrm{P}_{1}$ & 24 & 8.90 & 220 & 2.25 & 325 & 6.02 & 6.35 \\
\hline $\mathrm{P}_{2}$ & 29 & 8.40 & 235 & 1.29 & 340 & 6.78 & 6.02 \\
\hline $\mathrm{P}_{3}$ & 24 & 8.34 & 300 & 3.11 & 286 & 5.43 & 5.25 \\
\hline $\mathrm{P}_{4}$ & 32 & 8.55 & 245 & 2.53 & 260 & 5.25 & 4.12 \\
\hline $\mathrm{P}_{5}$ & 31 & 8.55 & 240 & 2.97 & 249 & 4.93 & 5.77 \\
\hline $\mathrm{P}_{6}$ & 28 & 8.42 & 220 & 1.56 & 325 & 4.99 & 5.25 \\
\hline $\mathrm{P}_{7}$ & 30 & 8.38 & 215 & 2.74 & 290 & 5.77 & 5.89 \\
\hline $\mathrm{P}_{8}$ & 29 & 8.21 & 210 & 3.67 & 288 & 5.45 & 4.78 \\
\hline $\mathrm{P}_{9}$ & 28 & 8.09 & 230 & 1.87 & 335 & 6.64 & 7.02 \\
\hline $\mathrm{P}_{10}$ & 29 & 8.42 & 235 & 3.98 & 312 & 7.01 & 5.65 \\
\hline $\mathrm{P}_{11}$ & 30 & 8.24 & 210 & 2.73 & 319 & 6.12 & 5.77 \\
\hline $\mathrm{P}_{12}$ & 32 & 8.10 & 205 & 1.56 & 339 & 5.98 & 5.21 \\
\hline $\mathrm{P}_{13}$ & 25 & 8.92 & 210 & 2.12 & 355 & 6.10 & 7.25 \\
\hline $\mathrm{P}_{14}$ & 23 & 8.10 & 240 & 2.68 & 322 & 5.55 & 4.65 \\
\hline
\end{tabular}

Table2. WHO Guideline for Drinking Water Quality.1984

\begin{tabular}{|c|c|}
\hline Parameter & Standard value \\
\hline $\mathrm{pH}$ & $6.5-8.5$ \\
\hline Total Hardness & $300 \mathrm{mg} / \mathrm{l}$ \\
\hline TDS & $200-250 \mathrm{mg} / \mathrm{l}$ \\
\hline Turbidity & $5-10 \mathrm{NTU}$ \\
\hline DO & $4.6 \mathrm{t} 06.0 \mathrm{mg} / \mathrm{l}$ \\
\hline BOD & $6 \mathrm{mg} / \mathrm{l}$ \\
\hline
\end{tabular}

\section{CONCLUSION}

For human existence it is essential to have the availability of water supply adequate in term of both quantity and quality. At the begging of civilization the man recognized the importance of water from a quantity view point and accordingly civilization development around water bodies. They could support agriculture, transportation and provide potable water. Earlier the humans could judge water quality only through the physical sense of sight, taste and smell. Later on the biological chemical and medical sciences developed methods of major water quality and to determine and its effects on human health and well being. Knowledge of the parameter most commonly associated with potable water quality is must. Therefore protection of potable water quality is essential, to effectively regulate potential sources of impurities. We must understand the behavior of impurities in the water. We can predict the environment impact. PH of all stations was under limit. Most of stations were found higher values of hardness. Due to higher hardness values import economic pressure on consumer. Values of total dissolved solid were higher at some stations and other stations samples are under limit. DO and BOD of common studied potable water is also under limit as per prescribed WHO guidelines.

\section{ACKNOWLEDGEMENTS}

We express our sincere thanks to the Head, Department of Chemistry, for successful completion of this research work 


\section{REFERENCES}

[1] G.K. Kannan, Limn logical studies on river Mandakini with intension to evolve an approach for conservation and management phD. Thisis in Environmental science, MGCGV Chitrakoot (1995).

[2] M.K. Singh, Dhaneshwer jha and Jyiti Jadoun, Assessment of physic-chemical status of Ground Water samples of Dhplpur District, Rajasthan, India. International Journal of Chemistry, 4 (4), 96-104 (2012).

[3] WHO, Internal Standards for Drinking Water Monograph Series No.42 (1999).

[4] Raja R E, Lydia Sharmila, Princy Merlin, Chritopher G, Physico-Chemical Analysis of Some Groundwater Samples of Kotputli Town Jaipur, Rajasthan, Indian J Environ Prot., 22(2), 137, (2002).

[5] Standard Methods of water and Waste Water Analysis, APHA, AWWA, USA (2005).

[6] Arvind Prasad Dwivedi and Indra Prasad Tripathi,Quality Assessment of Ground Water and Surface Water Samples Collected from Two Different Zone of Central India. International Journal of Scientific and Technology, 5 (4), 199-204 (2016)

[7] Indra Prasad Tripathi and Arvind Prasad Dwivedi,Multivariate Analysis of Soil and Ground Water Quality in Sidhi district of Vindhya Plateau, Journal of Applicable Chemistry, 4(1),178-203(2015).

[8] Arvind Prasad Dwivedi and Indra Prasad Tripathi,Chemistry of Soil and Ground Water in Panna District of Vindhya Pradesh, AARJMD, 131),60-86 (2015).

[9] Indra Prasad Tripathi and Arvind Prasad Dwivedi,Analysis of Physico-chemical Parameters and Correlation Coefficient of Ground Water Samples in Residential Area of East Zone of Central India, International Journal of Information Research and Review, 3(3),2078-2086 (2016).

[10] Indra Prasad Tripathi and Arvind Prasad Dwivedi, Quality and Assessment of ground water in Satna, Madhya Pradesh, Journal of Applicable Chemistry, 4(2), 615-623(2015).

[11] A.P. Dwivedi, I.P. Tripathi and M.Suresh Kumar,Assessment of Soil and Ground Water Quality in Rewa District of Vindhya Plateau (India), J Environ. Science and Engg. 55(1) 51-64 (2013).

[12] Indra Prasad Tripathi and Arvind Prasad Dwivedi,Charecterization of Diffuse Chemical Pollution in Satna District of Vindhya Region, India. International Research Journal of Environment Science, 2 (11), 46-60 (2013).

[13] Raja R E, Lydia Sharmila, Princy Merlin, Chritopher G, Physico-Chemical Analysis of Some Groundwater Samples of Kotputli Town Jaipur, Rajasthan, Indian J Environ Prot., 22(2), 137, (2002).

Citation: A. Prasad Dwived, "Physico-Chemical Characteristics of Potable Water in Chitrakoot Region District", International Journal of Advanced Research in Chemical Science (IJARCS), vol. 4, no. 5, pp. 30-35, 2017. http://dx.doi.org/10.20431/2349-0403.0405004

Copyright: (C) 2017 Authors. This is an open-access article distributed under the terms of the Creative Commons Attribution License, which permits unrestricted use, distribution, and reproduction in any medium, provided the original author and source are credited. 